\title{
INTERNATIONALISATION OF HIGHER EDUCATION BASED ON LEAN MANAGEMENT PRINCIPLES: CASE STUDY OF JAGIELLONIAN UNIVERSITY ${ }^{5}$
}

\author{
Vitalii Kurylo, Iryna Myhovych \\ State Institution “Luhansk Taras Shevchenko National University”, Starobilsk, Ukraine \\ donluga@gmail.com, irina.migovich@gmail.com
}

\begin{abstract}
The paper deals with the phenomenon of lean management in higher education analysed within the context of internationalisation process in Polish higher education as a means of ensuring inclusive global higher education space. Lean management is looked upon as one of the $21^{\text {st }}$ century models of university management transplanted from the sphere of private enterprises and business companies' management. The empirical analysis has been conducted with the use of statistical data provided by the official website of Jagiellonian University, Krakow, Republic of Poland. The data have been collected in accordance with the following internationalisation process indicators: amount of bilateral Memoranda of Understanding; Inbound Mobility: number of foreign students who have completed the full cycle bachelor's / master's degree; Inbound Mobility: number of foreign students who have completed the full cycle PhD's degree; Inbound Mobility: participation in Quin Jadwiga Fund granting schemes; Inbound Mobility: participation in Erasmus / Erasmus+ Programme; Outbound Mobility: participation in Erasmus / Erasmus+ Programme; number of outbound mobile students in accordance with bilateral agreements; number of inbound mobile students in accordance with bilateral agreements; number of outbound mobile staff in accordance with bilateral agreements; number of inbound mobile staff in accordance with bilateral agreements. The collected data have shown gradual increase of internationalisation process indicators and allowed concluding that the introduction and support of lean management principles in higher education promotes the intensification of the internationalisation process.
\end{abstract}

Keywords: lean management; higher education; higher education management; internationalisation process; academic mobility.

\section{Introduction}

Modern higher education institutions (HEIs) function within the global competitive environment (Barth et al., 2007). The pressure to achieve scientific and didactic excellence, while at the same time meeting the requirements in terms of accountability, transparency, economics, flexibility, effectiveness, efficiency and quality of operation is increasing year by year, and the year 2020 became no exception. In 2020 HEIs around the world faced, along with numerous political, legal, economic, social, and technological challenges, the COVID-19 crisis, which forced the global academic community to reflect on how the 2020 unprecedented situation could be transformed into an opportunity, as it has always been done before.

The COVID-19 outbreak has posed enormous challenges to HEIs, as well as to the process of providing educational and research services. While forming their own development strategies, it is necessary for HEIs to ensure a competitive policy at the educational services market and look for new effective approaches to management. One of the most promising approaches at present is focused on the idea of using the concept of lean production or lean management in higher education (Balzer, 2010; Douglas et al., 2013; Drotz, 2014; Liker, 2004), based on flexible methodologies, principles of effective resource management, attention to consumer needs, concentration on the problem of eliminating all types of resource losses, effective use by management entities of their own intellectual potential. Lean management is a unique management principle (concept) that includes tools, which allow managing any organization (including a HEI) faster, more economically, and more efficiently (Antony et al., 2012; Antony, 2014; Holt et al., 2007; Lawrence and Cairns, 2015). Lean management application becomes particularly relevant in the segment of internationallyresearch-oriented universities focused on global rankings as indicators of internationalization and performance evaluation (Altbach and Knight, 2007; Bracht et al., 2006; Knight, 2012; Zitt and Filliatreau, 2007).

The end of the $20^{\text {th }}$ century in higher education was marked by the general understanding among the key actors that the concepts and models of university management which were widely used at the time had become less effective. Such understanding was based on the fact that these concepts and models only occasionally took into account the interconnection of higher education and society which is realised through educating and training of students as future professionals and mindful citizens. Parallel to this the paradigm of New Public Management appeared, which presupposed running public service organizations in a business-like manner with the purpose to improve their efficiency (McLaughlin et al., 2002). Gradually Process Management concepts from business manufacturing companies became implemented at universities. The Total Quality Management (including quality management systems compliant with ISO

(C) Vitalii Kurylo, Iryna Myhovych. 2021. Published by Igor Sikorsky Kyiv Polytechnic Institute. This is an Open Access article distributed under the terms of the licence CC BY 4.0 
9001), business process re-engineering or process management became increasingly popular in educational sector (Douglas et al., 2015; Hess and Benjamin, 2015; Koch and Cebula, 1994; Koch and Fisher, 2010; Quinn et al., 2009). The new managerial paradigm in higher education became as successful, as in mediumand-small enterprises and huge manufacturing companies.

Numerous researches conducted in educational sector have shown that the implementation of Process Management concepts brings positive effects to the organizational and technical system of HEIs (Balzer et al., 2016; Laredo, 2007; Lisowska and Ziemiñski, 2012; Mainardes et al., 2010; Wiegel and Hadzialic, 2015). However, the sustainability of these effects is often questioned (Bargh et al., 1996; Comm and Mathaisel, 2005; Grudowski and Leseure, 2013; Grudowski and Szefler, 2015). It has been identified that mechanical, top-down, enforced manner of Process Management concepts implementation arouses resistance and conflicts among university employees. There is no deep self-reflection on the essence of the university's activity, its mission, specificity of implemented processes and current conditions. The organizational culture of a university usually neither supports nor provides opportunities to promote and consolidate positive changes.

Therefore, the dilemma of how to change the model of university management, while respecting the principles and values that constitute the University, has been growing for years (Alves and Raposo, 2010). The conducted research clearly indicates that a permanent change in the university management model is possible only through the change in the organizational culture. And the latter is possible only through profound self-reflection on the essence of the university's activities, its mission, the current state of affairs and development goals (Höfer and Naeve, 2017). Considering the above, more and more universities all over the world, in Polish Republic as well, start applying a new approach referred to as Lean Higher Education (Balzer, 2010) or Lean University (Maciąg, 2011; 2016; 2019), based on the paradigm of New Public Management and the concept of lean management.

Lean management is the expression of the willingness on each hierarchical level of a HEI to question one's own behaviour, to learn from mistakes and to continuously develop new solutions towards waste-free processes. It stands for permanent customer-focused and value-adding thinking and acting (Womack and Roos, 1996). Lean management is a humanistic concept of management based on profound self-reflection on organizational, technical, and cultural conditions of a university. It is based on two fundamental values that are close to the traditional academic ethos: 1) respect for people; 2) constant striving for perfection. In the operational dimension, the implementation of these values is manifested through actions aimed at increasing the value created for the school's stakeholders (students, employees, scientists, lecturers, etc.) by simultaneously minimizing or eliminating all sources of waste (Thomas et al., 2013).

The first discussions on the use of lean management for the improvement of university management were initiated in 1995 while debating on leadership in higher education. Currently, more than several hundred universities around the world declare that they use lean management to improve their management models and systems. They co-operate within the international LeanHE Hub network, which is the global organization focused on networking, sharing best practice, and supporting the delivery of lean management public events. The activity of the organization is performed in accordance with the following principles: 1) it is expected to be practice-based and action-focused;2) it relies on conducting research on educational management to support and enhance applied learning; 3) it is aimed at staff that work within higher the education sector and are engaged in continuous process of institutional improvement.

Having analysed the theoretical and methodological material on the subject of research, as well as having performed the comprehensive analysis of lean management principles application within Jagiellonian University (Krakow, Polish Republic) functional profile, the following observation has been made researchers in the field of higher education lean management state that there is still certain lack of in-depth institutional transformations towards becoming lean HEIs. It is connected with the fact that most universities around the world, intuitively relying on their experience in educational sphere, develop this completely new for them direction of managerial culture (Grudowski and Leseure, 2013; Maciag, 2011; Marchwiński et al., 2010; Shattock, 2003; Woźnicki, 2014). Polish higher educational sector, according to Woźnicki (2014), demonstrates that the majority of Polish universities, especially larger public educational institutions, despite their essential role in strengthening the innovative potential of the national economy, did not adapt their organizational systems to current trends in the area of quality management, which involves, among other, strong focus on lean culture and internationalization (Woźnicki, 2014). Despite the dynamic debates over these issues in Polish higher education and numerous legislative changes in this field, as well as the endeavours of Polish universities and the Ministry of Science and Higher Education to have an increasingly more pro-quality and entrepreneurial international academic co-operation, there is still room for growth.

Thus, the aim of this paper is to outline the theoretical and methodological basis for the application of lean management principles in higher education, as well as to develop the key guidelines for lean 
management implementation in HEIs as one of the ways to enhance internationalization in higher education (on the basis of the analysis of Lean Culture at Jagiellonian University in Krakow, Polish Republic). The conducted comprehensive analysis allows for identification of the perspectives and opportunities of using lean management from the perspective of various higher education sector stakeholders. As a consequence, this might enable the development of institutional improvement strategies consistent with the principles of lean and engaging different groups of stakeholders. The summary provides directions for further research related to the possibilities of using lean management concept in the context of higher education.

\section{The Context of Lean Management for Internationalised Higher Education}

In order to achieve the aim of the research, it is relevant to demonstrate how the internationalization process within the higher education sector can be supported and strengthened by means of application of lean management principles and enhancement of the institutional Lean Culture. The case study of lean management principles application in Jagiellonian University, Krakow, Polish Republic, allowed us to identify eleven lean-focused projects initiated or continually supported by the University at all levels (see some of them outlined below):

- the institutional final of the Coimbra Group 3-Minute-Thesis took place for the first time at the Jagiellonian University (CG 3MT JU). The competition was co-organised by the JU Association of Doctoral Students, represented by its head Paweł Kupis and deputy head Joanna Świt. The rules of competitions organised around the world under the name 3 Minute Thesis (3MT) were developed in 2008 at the University of Queensland in Australia. Since 2017, the Coimbra Group - a network of the oldest and most prestigious universities in Europe - has been running the final of the 3MT competition at its annual general meeting. At the CG 3MT, PhD students present their research concepts during a three-minute presentation in English, using only one slide. Participation in the competition, apart from the possibility of winning valuable prizes, allowed the $\mathrm{PhD}$ students to master the art of academic public speaking, as well as face the difficult challenge of presenting the research concept in just three minutes with only one slide available. It is hoped that the success of this competition will make it a permanent part of the annual calendar of events at the Jagiellonian University (Uniwersytet Jagielloński, 2020).

- international project UNA.TEN - “Transfer Emergency Now! 10 days for change" organised by Una EuropaUniversity Alliance Europe. UNA.TEN is an open innovation design process aimed at developing solutions to address real challenges in COVID19 post-emergency times. For 10 days, under the supervision of mentors, students' teams and $\mathrm{PhD}$ students from the UNA Europa partner universities worked on their own solutions to current challenges in four areas: 1) How to rethink entertainment and cultural activities during the COVID post-emergency period? 2) How to protect our privacy and help fight dangers, fears and misconceptions in a digital world? 3) How to ensure traveller's safety when COVID-19 has not been fully defeated yet? 4) How to avoid food waste on the field level due to supply chain disruption? The projects attracted a lot of interest and became an opportunity for the first virtual mobility, so we are already planning further initiatives (Uniwersytet Jagielloński, 2020).

- International students in Poland 2020 Conference was organised by the Rectors of Academic Schools in Poland, "Perspektywy" Education Foundation and Łódź University of Technology. It gathered many distinguished guests from various educational institutions in Poland, creating an opportunity for sharing views and ideas on the internationalisation of higher education, admission of international students to Polish universities as well as international marketing strategies, related to attracting students from abroad. One of the events of the conference programme was the ceremony of awarding "Stars of Internationalisation". The awards honour outstanding representatives of Polish HEIs for their remarkable achievements in the field of universities' internationalisation. The award is granted by a Chapter, which includes major Polish institutions and organizations involved in the development of the process of internationalisation (Uniwersytet Jagielloński, 2020).

- International Visitors Centre provides professional support services for international guests (mainly researchers, visiting professors, teachers, post-docs, exchange visitors). Such services have become a key element to attract 'high potential' to the university, develop international co-operation in research and education. Services provided to international guests can help them feel comfortable in a new country and new university environment. They contribute to enhancing scientific knowledge and professional development. Taking into consideration the growing number of international guests coming to the Jagiellonian University each year (in the last 15 years this number increased from 2,970 to 4,975 per year), the University has seen the urgent need for creating and developing activities carried out by a welcome centre. Responding to challenges posted by modern, international standards, the Jagiellonian University has established a Welcome Centre for International Guests as part of its International Relations Office. The team 
of Jagiellonian University Welcome Centre provides general information, advice and support for guests in preparation for and throughout their stay at Jagiellonian University. The areas of expertise include: entry conditions: visa, residence permits, local authorities, information prior to departure and upon arrival in Poland; work-related issues - welcome pack for new employees at Jagiellonian University, i.e. consultancy regarding social security, insurance and taxation issues; accommodation - information, advice and support in finding suitable housing; family and children - information and consultancy regarding child care and schooling, events and individual advice to life partner; Jagiellonian University structure - different resources at the University; life in Poland and Kraków - references and tips for recreational activities and leisure time in Kraków and its vicinity; cultural programme and welcome events - special welcome events for international guests and their families (Uniwersytet Jagielloński, 2020).

- a series of trainings dedicated to Jagiellonian University employees under the Process Management programme has been launched, the aim of which is to acquire modern knowledge and skills in the field of Lean Management, including project management, process management, team management, etc.

- creation of co-operation networks and communities of practitioners, which constitute a platform for the exchange of knowledge and experience between universities. An example of this platform is nationwide seminars on Lean Higher Education, organised by J. Maciąg in the Jagiellonian University Institute of Public Affairs every six months. The main focus of the events is on implementing the process approach and lean management and maintaining changes in higher education. Research conducted within the events shows that lean management, bearing in mind the essence of this concept and the way of implementing changes based on self-reflection, can be successfully used in HEIs. The main benefits include: changing the attitudes of employees, creating and working in interdisciplinary teams, better communication and co-operation, respect, mutual understanding, looking at the process through the eyes of the client (student, employee, doctoral student, lecturer) and increasingly more effective use of university resources by eliminating waste, freeing students and administration from unnecessary bureaucracy through slimming down the processes and procedures, increasing the transparency of action, ordering documentation and effective management. Then the university becomes a friendlier place to work, study, teach and conduct scientific activities. It is worth stressing that the changes introduced are evolutionary and not revolutionary in nature. The authors of the changes are the employees themselves, so they are more willing to become involved and are motivated to maintain and further improve them (Uniwersytet Jagielloński, 2020).

\section{Strategic Goals of Lean Management Application to Enhance Internationalization of Higher Education}

The empirical analysis of lean management principles application as one of possible means to enhance the internationalization within the higher education sector has allowed us to characterise the current state of internationalization and Lean Culture development, as well as to identify the most typical features of lean application with regard to internationalization by grouping them into four strategic goals (Fig. 1). Each of them includes several operational objectives, specific tasks, mechanisms for their implementation and expected results.

Strategic goal 1. Modernization of content, quality assurance of education, formation of modern educational environment is one of the most important goals in the structure of strategic priorities for lean management principles application. It contains four objectives that cover a wide range of tasks - from modernization of educational environment to improvement of modern quality assurance system of Polish higher education. The importance of this strategic goal is determined by the need for a fundamental update of the structure and content of the educational process focused on competency-based learning. Updating the content of education includes a wide variety of tasks and specific mechanisms, including the introduction of new professional and educational standards with a competency-based approach, modernization of the methodology and development of educational syllabi, curricula, training programmes, unification of curricula for the same-type occupations, elaboration of new textbooks, including electronic, licensing new specialities, etc.

New educational curricula should be based on a modular competency approach that ensures: a) flexibility of educational process; b) focus on learning results; c) tracking of intermediate learning outcomes, adjusting them if necessary; d) acquisition of certain competencies in a short term period; e) universal of structure of study modules taught to different groups of learners; f) a lifelong learning orientation. The modular competency approach means changing the logic of the content and organization of the learning process, in particular, the transition from knowledge acquisition through the study of subjects to the acquisition of competencies defined by employers and educators. 

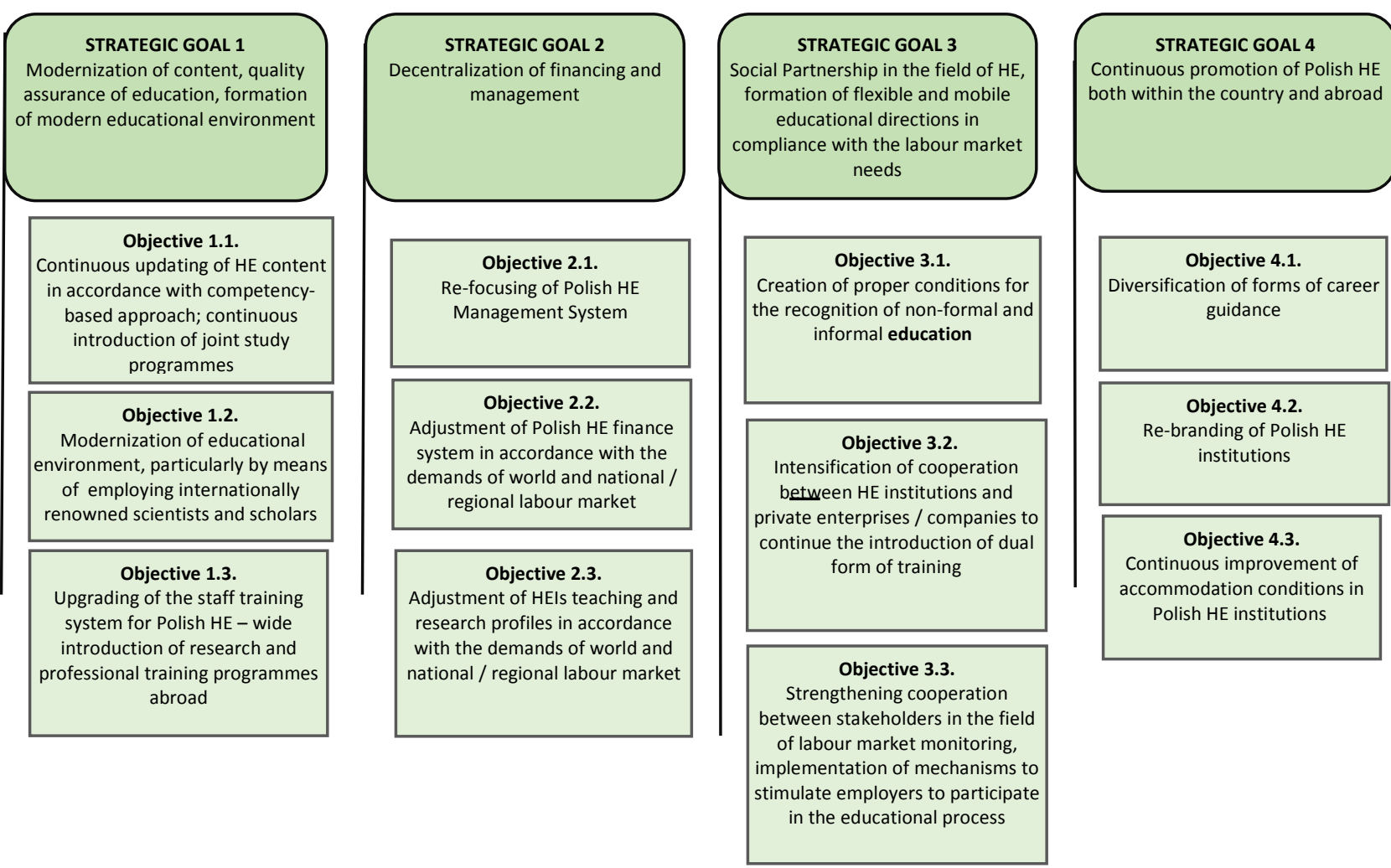

Figure 1. Strategic goals for the application of lean management principles

Changes in the forms and methods of training require updating the system of learning outcomes assessment. This update means the transition from evaluation of knowledge and skills to an integrated and independent assessment of competencies acquired not only through formal education but also through nonformal education or work experience. Moreover, it is equally important to engage employers in the development of an internal and external system for the assessment of the quality of education. The establishment and support of centres for assessment of competencies obtained through non-formal learning and work experience abroad are additional perspectives of the introduction of lean management principles in the sphere of higher education.

Strategic goal 2. Decentralisation of financing and management opens the way to building an effective dialogue between HEIs, employers, and local authorities. As the experience of many European countries shows that decentralization is one of the real ways to optimise the financial expenses, strengthen the influence of regional authorities and employers on the development of higher education. This approach encourages the local authorities to regularly monitor the labour market, take into account its features, dynamics. An important task is to diversify financial resources, optimise the costs of HE institutions maintenance, engage international donors' funds to the sphere of higher education, participate in internationally funded research projects, as well as objectively determine the cost of training staff of different occupations, considering the complexity of the speciality.

Strategic goal 3. Social partnership in the field of higher education, formation of flexible and mobile educational directions in compliance with the labour market needs. Starting from the end of the $20^{\text {th }}$ century and up to now a considerable part of Polish population acquired qualifications and skills through non-formal and informal education. However, at present, there is difficulty with the recognition of nonformal and informal education. In order to solve this problem which will improve the situation in the labour market, it is necessary to develop assessment criteria and establish qualification centres for the evaluation and recognition of non-formal and informal education.

Involving employers in solving problems of Polish higher education addresses the needs of both the educational institutions and the companies. Main enterprises for which HEIs train the workforce might provide training centres, modern equipment, and conduct training for students in real workplaces. Without involvement of employers, it is impossible to solve the issue of developing a dual form of education. Higher education should take into account the needs of the labour market which, in fact, is formed by private enterprises. It is almost impossible to obtain objective information about the needs for specialists in different occupations without the involvement of employers. This is especially true for small and mediumsized enterprises, since they are hardly involved in gathering information on existing vacancies. Therefore, 
in this respect, the cooperation of Polish higher education and employers, as well as representatives of regional authorities, is extremely important.

Strategic goal 4. Continuous promotion of Polish higher education, both - in the native country and abroad. Among a range of measures to continuously promote Polish higher education career guidance is of great importance. Its relevance is increasing, as the real battle for applicants continues in the educational services market. Diversification of career guidance forms is a difficult task, since it requires non-standard solutions in this field. The focus in the process of career guidance modernization should be on the use of information technology, since young people receive most of information not from television or newspapers, but from social networks, Internet and so on.

Thus, the reflexion on the results of applying lean management principles to promote the internationalisation of HE highlights the need to stop defining the degree of internationalisation only by the number of foreign students enrolled at Polish universities. Instead, the focus should be made on the development of adjusted teaching and research profile, which would substantially be based on international partnership leading to high quality of teaching and research through creating joint study programmes conducted in foreign languages, international doctoral programmes and employing internationally renowned scientists and scholars. In the case of Jagiellonian University, the introduction and support of the mentioned principles of lean management application have led to the increase in the formal statistical indicators of internationalisation starting from the year 2010 and up to 2020, when this study was conducted (Table 1).

Table 1. Statistical indicators of internationalisation process at Jagiellonian University, Krakow, Republic of Poland (Uniwersytet Jagielloński, 2020)

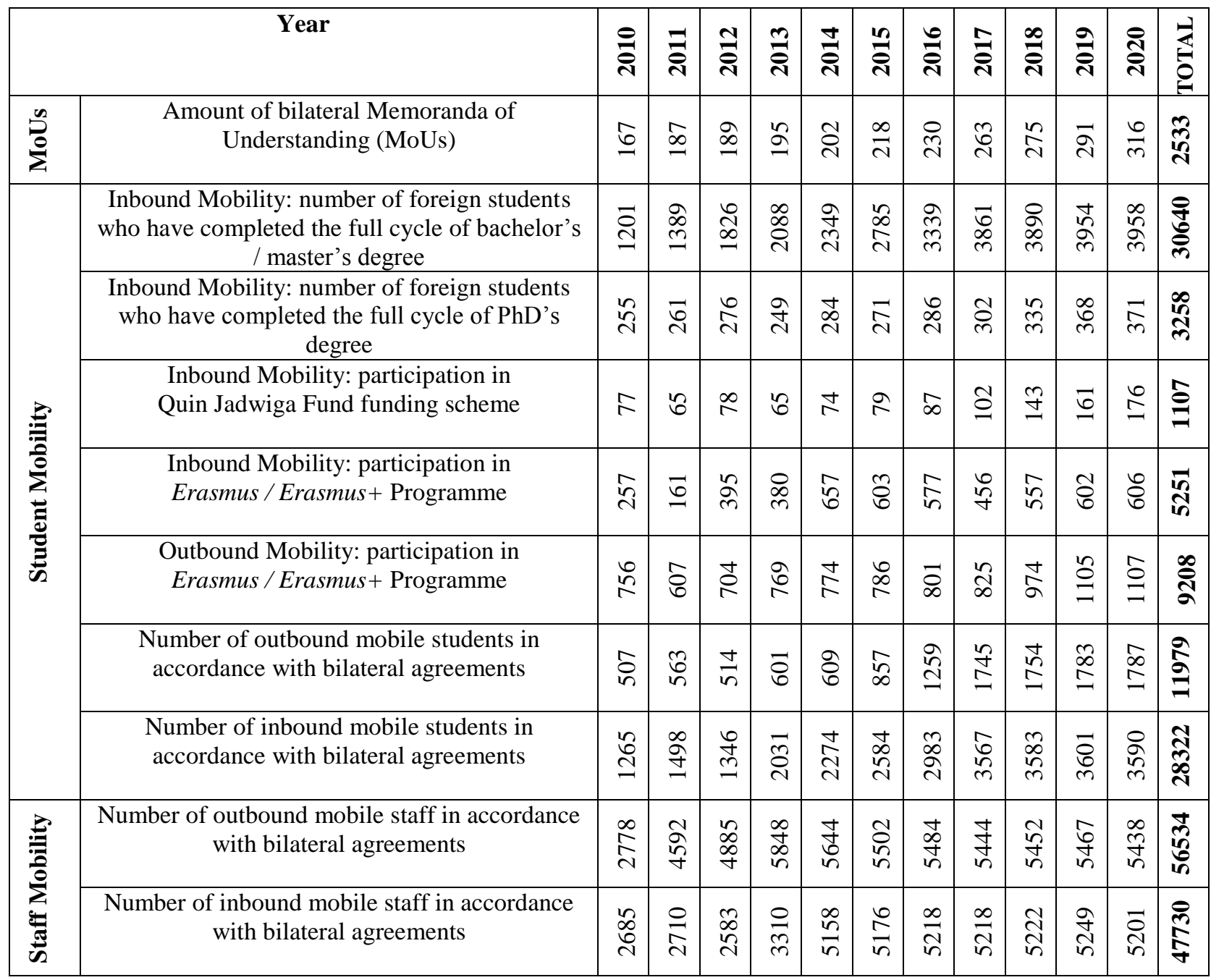

The performed case study of application of lean management principles at Jagiellonian University, Krakow, Republic of Poland, has made it possible to outline the main objective of higher education lean management - to create a management system that would fully prevent errors and ensure the absence of 
inefficient work in the educational process, as well as contribute to the continuous development of twentyfirst century skills of University graduates. For this purpose, numerous techniques and tools for designing, implementing, evaluating and improving processes and the university management model should be used. Dedicated departments, teams, internal networks of change agents and other forms of co-operation for the improvement of the university culture are created. One of the conditions for the success of change is specialised trainings for employees and their involvement in improvement projects. A change in organizational culture takes place through a change in the attitude of each employee of the university. This requires the full involvement of university management at all levels and the provision of resources (material, information, human and financial) for the implementation of the cultural change programme and the university management model (Hurley and Yorkstone, 2019).

\section{Key guidelines for lean management application to enhance internationalisation of higher education}

The key guidelines for the application of lean management principles to enhance the internationalisation of higher education are as follows (note, though identified on the basis of the empirical analysis of Polish higher education, the proposed guidelines are considered to be of universal nature):

1) with the aim of strengthening lean management and Lean Culture as parts of the enhancement mechanism for institutional internationalization it is worthwhile to establish Strategic Change Councils at HEIs, consisting of university Chancellor, Presidents, campus and system leadership, who are familiar with strategic institutional priorities, guiding principles, priority areas and who will act as institutional change agents identifying and prioritising campus-based process improvement opportunities;

2) for the purpose of consolidating campus-based improvement process and given the likelihood of online learning continuing through 2021 academic year, it is advisable for HEIs to reflect upon and elaborate renewed models of internationalisation at home based on lean methodology, which can be used to deliver courses in online environment. It is important for this process to involve the entire higher educational institution community: top management, academic and administrative staff, students;

3 ) it is as well advisable for HEIs to reflect on the design of online and blended courses, to elaborate and introduce Lean Concepts of Online Classes consisting predominantly of the following: focus on key stakeholders - selecting readings and assignments in consultation with employers, experts in field of respective area, and graduates of educational programme working in the field; establishing feedback loops to collect feedback on online content; Flow - removing tasks / readings / assignments that do not add value; removing extra steps or assignments that are redundant or not current; ensuring that course layout is clear and information flows to the student without interruption; Pull - selecting online class meeting times based on students' demands; selecting online chat session times based on students' demands; Stop and Control Mistakes - provision of immediate feedback to students so that they are able to correct mistakes; Visual Control - inclusion of visual diagrams for key assignments and a course calendar; Continuous Improvement - collecting feedbacks from employers, alumni, students, and faculty to improve online course delivery, as well as regular course evaluations (at least 2-3 times during the semester); Standardised Approach based on creating standardised course template for online courses to reduce variation (Emiliani, 2004; Krehbiel et al., 2015);

4) while applying Lean Management principles, HEI top management representatives should focus attention on faculty members who wish to integrate lean principles in their instructional practices while advancing "internationalization-at-home" process (Knight, 2010); this might help in exploring challenges that faculty faces as they implement lean practices in the course delivery methods;

5) as a follow up, it is considered to be worthwhile to implement institutional changes to academic procedures and to update existing, possibly outdated, curricula, institutional regulations, protocols, etc. in line with lean methodology and internationalization principles.

\section{Limitations}

The key limitation of the present-day research is caused by the representativeness of the collected statistical data for the performed empirical analysis: 1) it is focused mainly on one Polish higher educational institution; 2) time period for data sampling is limited to ten years starting from 2010 and ending with 2020. The non-random (preliminary identified) selection components related to internationalization indicators, as well as the overall sampling considerations, have also limited the research analysis frame. 


\section{Conclusions}

The analysis of the lean management principles application in the sphere of higher education with the aim to enhance the internationalization process in higher education has allowed us to conclude that the implementation of lean management principles in higher education contributes to important transformations of Polish higher education: 1) strengthening of international research and educational activities; 2) increase in the number of foreign students (due to international mobility);3) attention to intercultural dialogue and cooperation in the process of conducting scientific and educational activities, respect and hospitality for representatives of other cultures and religions who come to study and conduct research at Polish universities; 4) reduction of state funding for research and education; 5) increasing demand for higher education as a consequence of the commercialisation and decentralisation of education; expanding access to the national education through the introduction of educational programmes for foreign citizens in English (the notion of internationalization at home).

The performed case study has made it possible to conclude that for students and university employees, lean management presents an opportunity to gain new competencies, learn lean technologies, initiate own lean projects, gain skills in working in teams with a focus on specific results and continuous improvement. For HEIs, on the one hand, this is an increase in consumer satisfaction with the quality and timely services, a reduction in the waiting time for a consumer to receive services, transparency of the organization of processes for consumers, formation of personnel competencies to quickly identify and solve problems, supporting leaders among staff who are capable of making improvements based on a project approach. On the other hand, this type of management means saving time, resources, costs, increasing productivity, improving efficiency and quality of management, increasing competitiveness.

Thus, we can conclude that in the transition to lean management, a university needs such a model of a systemic lean project that will expand opportunities and give significant effects expressed in continuous improvement of the internal processes at the university, eliminating all types of losses, and increasing labour productivity by the implementation of operational activities of administrative and teaching staff, quality management, optimization and rational use of the university resources, expansion of the scientific base, development of corporate lean culture.

\section{Acknowledgements}

The present study was conducted within Doctor of Pedagogical Sciences research The Process of Internationalization and Its Impact on the Transformation of National Higher Education Systems in Eastern Europe in the late XX - early XXI century, as well as a part of the ongoing project Management of Internationalization 2020-2021 within 2020 German-Ukrainian Academic Cooperation supported by the Ministry of Education and Science of Ukraine.

\section{References:}

Altbach, P. G., Knight J. (2007). The Internationalisation of Higher Education: Motivations and Realities. Journal of Studies in International Education, 1, 290-305. https://doi.org/10.1177/1028315307303542.

Alves, H., Raposo, M. (2010). The Influence of University Image on Students' Behavior. International Journal of Educational Management, 24(1), 73-85. https://doi.org/10.1108/09513541011013060.

Antony, J., Krishan, N., Cullen, D., Kumar, M. (2012). Lean Six Sigma for higher education institutions (HEIs): challenges, barriers, success factors, tools/techniques. International Journal of Productivity and Performance Management, 6(8), 940-948. https://doi.org/10.1108/17410401211277165.

Antony, J. (2014). Readiness factors for the Lean Six Sigma journey in the higher education sector. International Journal of Productivity and Performance Management, 63, 2, 257-264. https://doi.org/10.1108/IJPPM-04-2013-0077.

Balzer, W.K. (2010). Lean Higher Education - Increasing the Value and Performance of University Processes. New York: Taylor and Francis Group.

Balzer, W., Francis, D., Krehbiel, T., Shea, N. (2016). A review and perspective on Lean in higher education. Quality Assurance in Education, 24(4), 442-462. http://dx.doi.org/10.1108/QAE-03-2015-0011.

Bargh, C., Scott, P., Smith, D. (1996). Governing Universities: changing the culture? Buckingham: SRHE and Open University Press.

Barth, M., Godemann, J., Rieckmann, M., Stoltenberg, U. (2007). Developing key competencies for sustainable development in higher education. International Journal of Sustainability in Higher Education, 8, 4, 416-430. Retrieved 16 March 2021 from: https://www.emerald.com/insight/content/doi/10.1108/14676370710823582/full/html.

Bracht, O., Engel, C., Janson, K., Over, A., Schomburg, H., Teichler, U. (2006). The Professional Value of ERASMUS Mobility. Final Report. Presented to the European Commission. Education and Culture. Retrieved 20 March 2021 from: file:///C:/Users/Iryna\%20Myhovych/Downloads/The_Professional_Value_of_ERASMUS_Mobility_Final_R.pdf.

Comm, C.L., Mathaisel, D.F. (2005). An exploratory study of best lean sustainability practices in higher education. Quality Assurance in Education, 13, 3, 227-240. http://doi.org/10.1108/09684880510607963

Douglas, A., Douglas, J., Antony, J. (2013). Gold in the Mine: Recognising Waste in UK HEIs Using Lean Thinking. Proceedings of First International Conference on Lean Six Sigma for Higher Education. Glasgow, Scotland, UK. 
Douglas, J., Antony, J., Douglas, A. (2015). Waste identification and elimination in HEIs: the role of Lean thinking. International Journal of Quality \& Reliability Management, 32(9), 970-981. http://dx.doi.org/10.1108/IJQRM-10-2014-0160.

Drotz, E. (2014). Lean in the Public Sector. Possibilities and Limitations. Sweden, Linköping: Department of Management and Engineering Linköping University Press.

Emiliani, M. L. (2004). Improving business school courses by applying lean principles and practices. Quality Assurance in Education, 12, 4, 175-187. http://dx.doi.org/10.1108/09684880410561596.

Grudowski, P., Leseure, E. (2013). LSS Plutus - Lean Six Sigma dla matych i średnich przedsiębiorstw. Warszawa: WNT.

Grudowski, P., Szefler, J. (2015). Stakeholders Satisfaction Index as an Important Factor of Improving Quality Management Systems of Universities in Poland. Logožar: University of Maribor, Faculty of Economics and Business Press.

Hess, J., Benjamin, B. (2015). Applying Lean Six Sigma within the university: Opportunities for process improvement and cultural change. International Journal of Lean Six Sigma, 6(3). http://dx.doi.org/10.1108/IJLSS-12-2014-0036.

Höfer, S., Naeve, J. (2017). The application of lean management in higher education. International Journal of Contemporary Management, 16(4), 63-80. http://dx.doi.org/10.4467/24498939IJCM.17.038.8261.

Holt, D., Armenakis, A., Field, H., Harris, S. (2007). Readiness for organizational change: The systematic development of a scale. The Journal of Applied Behavioral Science, 43(2), 232-255. http://dx.doi.org/10.1177/0021886306295295.

Hurley, B., Yorkstone, S. (2019). Growing a Lean approach in a changing university. Global Lean for higher education: A themed anthology of case studies, approaches, and tools. New York: Routledge.

Knight, J. (2010). Higher Education Crossing Borders: Programs and Providers on the Move. Higher education in a global society. Northampton: Edward Eigar.

Knight, J. (2012). Concepts, Rationales, and Interpretive Frameworks in the Internationalization of Higher Education. The SAGE Handbook of Intercultural Competence. SAGE Publications.

Koch, J., Fisher, J. (2010). Higher education and total quality management. Total Quality Management, 9(8), 659-668. http://dx.doi.org/10.1080/0954412988136.

Koch, J., Cebula, R. (1994). In Search of Excellent Management. Journal of Management Studies, 31(5), 681-699. http://dx.doi.org/10.1111/j.1467-6486.1994.tb00634.x.

Krehbiel, T. C., Ryan, A. W., Miller, D. P. (2015). Lean learning: University's challenges lead to $\$ 27.2$ million in cost improvements. Quality Progress, 48, 2, 39-45.

Laredo, Ph. (2007). Revisiting the Third Mission of Universities: Toward a Renewed Categorization of University Activities? Higher Education Policy, 20(4), 441-456. http://dx.doi.org/10.1057/palgrave.hep.8300169.

Lawrence, H., Cairns, N. (2015). A guide to evidencing the benefits of business process improvement in higher education. UK: University of Strathclyde.

Liker, J. (2004). The Toyota way: 14 management principles from the world's greatest manufacturer. New York: McGraw-Hill.

Lisowska, A., Ziemiñski, F. (2012). Zarz ${ }^{1}$ dzanie jakoœci ${ }^{1}$ w urzêdach administracji publicznej. Zeszyty Naukowe Uniwersytetu Przyrodniczo--Humanistycznego w Siedlcach, 95, 87-93.

Maciąg, J. (2019). Lean Culture in Higher Education - Towards Continuous Improvement. Wydawnictwo Palgrave Macmillan, 2019. Retrieved 15 September 2020 from: https://www.palgrave.com/gp/book/9783030056858.

Maciąg, J. (2016). The determining role of organizational culture in the implementation of the lean management concept as exemplified by Polish universities. Retrieved 17 September 2020 from: http://www.leanhehub.ac.uk/conference/formerhosts.

Maciąg, J. (2011). How can an institution of higher education become lean? Methods of higher school restructuring. In Conference Papers Society for Research into Higher Education. Newport, Great Britain.

Mainardes, E. W., Alves, H., Raposo, M. (2010). An exploratory research on the stakeholders of a University. Journal of Management and Strategy, 1, 1. http://dx.doi.org/10.5430/jms.v1n1p76.

Marchwiński, Ch., Shook, J., Schroeder, A. (2010). Leksykon Lean. Ilustrowany słownik pojęć z zakresu Lean Management. Wrocław: Wydawnictwo Lean Enterprise Institute Polska.

McLaughlin, K., Osborne, S., Ferlie, E. (2002). New Public Management: New Trends and Future Prospects. Routledge.

Quinn, A., Lemay, G., Larsen, P., Johnson, D. (2009). Service quality in higher education. Total Quality Management \& Business Excellence, 20, 139-152. http://dx.doi.org/10.1080/14783360802622805.

Shattock, M. (2003). Managing Successful Universities. Maidenhead: SRHE and Open University Press.

Thomas, A., Francis, M., Fisher, R., Chilton, K. (2013). Can Higher Education Lean Itself Up? Can the Further Education Sector Show Us the Way? In Proceedings of First International Conference on Lean Six Sigma for Higher Education. Glasgow, Scotland, UK.

Uniwersytet Jagielloński w Krakowie: Dział współpracy międzynarodowej. Retrieved 15 December 2020 from: https://dwm.uj.edu.pl/pl_PL/o-dziale/historia-dzialu2.

Wiegel, V., Hadzialic, L. (2015). Lessons from higher education: Adapting Lean Six Sigma to account for structural differences in application domains. International Journal of Six Sigma and Competitive Advantage, 9(1), 72. http://dx.doi.org/10.1504/IJSSCA.2015.070104.

Womack, J., Roos, D. (1996). Lean thinking. New York: Simon \& Schuster.

Woźnicki, J. (2014). Uniwersytet jako kreacja instytucjonalna ambicji twórców i oczekiwań interesariuszy. Kraków: Wydawnictwo Uniwersytetu Jagiellońskiego.

Zitt, M., Filliatreau, Gh. (2007). Big is (made) Beautiful Some comments about the Shanghai ranking of world-class universities. In The World-Class University and Ranking: Aiming beyond Status. Romania: UNESCO-CEPES, Cluj University Press. 